\title{
RELATIONSHIP OF HIGH CIRCULATING CYSTATIN C TO BIOCHEMICAL MARKERS OF BONE TURNOVER AND BONE MINERAL DENSITY IN ELDERLY MALES WITH A CHRONIC HEART FAILURE
}

\author{
POVEZANOST POVEĆANOG CIRKULIŠUĆEG CISTATINA C I BIOHEMIJSKIH MARKERA \\ METABOLIZMA KOSTI I MINERALNE KOŠTANE GUSTINE KOD STARIJIH MUŠKARACA \\ SA HRONIČNOM SRČANOM INSUFICIJENCIJOM
}

\author{
Biljana Bozic Nedeljkovic ${ }^{1,2}$, Goran Loncar ${ }^{3}$, Tjasa Vizin $^{4}$, \\ Zoran Radojicic ${ }^{5}$, Vera Popovic Brkic ${ }^{6}$, Janko Kos ${ }^{4,7}$ \\ ${ }^{1}$ Faculty of Biology, University of Belgrade, Serbia \\ ${ }^{2}$ Institute for Medical Research, Military Medical Academy, Belgrade, Serbia \\ ${ }^{3}$ Clinical Hospital Zvezdara, Belgrade, Serbia \\ ${ }^{4}$ Faculty of Pharmacy, University of Ljubljana, Slovenia \\ 5 Institute of Statistics, Faculty of Organizational Sciences, University of Belgrade, Serbia \\ ${ }^{6}$ Faculty of Medicine, University of Belgrade, Serbia \\ ${ }^{7}$ Department of Biotechnology, Jozef Stefan Institute, Ljubljana, Slovenia
}

\begin{abstract}
Summary
Background: The aim of the study was to investigate the association of Cystatin $\mathrm{C}(\mathrm{Cys} \mathrm{C})$ to biochemical markers of bone turnover and bone mass, and to evaluate its prognostic significance in elderly males with chronic heart failure (CHF).

Methods: A prospective cohort study was executed on sixtyeight males (mean age 68 77 years) with mild to moderate CHF, together with 19 of corresponding age- and body mass index-matched healthy individuals who underwent cardiovascular, bone mineral density (BMD), and body composition assessment. Biochemical assessment of all subjects included NT-pro-BNP, parathyroid hormone (PTH), 25-hydroxy vitamin D (25(OH)D), CysC, and biochemical markers of bone turnover including osteocalcin $(\mathrm{OC})$, alkaline phosphatase (ALP), $\beta$-CrossLaps $(\beta-C T x)$, osteoprotegerin (OPG), and receptor activator of nuclear factor $\kappa B$ ligand (RANKL).

Results: Serum CysC was significantly increased in males with CHF in comparison to healthy control ones. A significant positive association was found between $\mathrm{Cys} C$ levels and

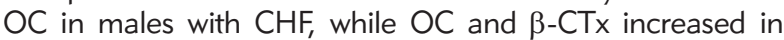
increasing $\mathrm{Cys} C$ tertiles. In multivariate regression analysis,
\end{abstract}

\section{Kratak sadržaj}

Uvod: Cilj studije je bio da se ispita povezanost cistatina C (CisC) i biohemijskih markera metabolizma kosti i mineralne koštane gustine, kao i da se proceni prognostički značaj CisC kod starijih muškaraca sa hroničnom srčanom insuficijencijom (HSI). Metode: Ovo istraživanje je prospektivna studija kohorte koju je činilo šezdeset osam muškaraca (prosečne starosti $68 \pm 7$ godina života) sa blagom do umerenom HSI i 19 zdravih osoba odgovarajuće starosti i indeksa telesne mase. Svi ispitanici su podvrgnuti proceni kardiovaskularnog sistema, mineralne koštane gustine i telesnog sastava. Biohemijska merenja kod svih ispitanika su uključivala određivanje NTpro-BNP, paratiroidnog hormona (PTH), 25-hidroksi vitamina $D(25(\mathrm{OH}) \mathrm{D}), \mathrm{CisC}$ i biohemijskih markera metabolizma kosti, uključujući osteokalcin (OC), alkalnu fosfatazu (ALP), beta-CrossLaps ( $\beta-C T x)$, osteoprotegerin (OPG) i ligand za receptor aktivator nuklearnog faktora $B$ (RANKL).

Rezultati: Serumski CisC je značajno povećan u muškaraca sa HSI u poređenju sa nivoom kod zdravih osoba. Značajna pozitivna povezanost detektovana je između nivoa $\mathrm{CisC}$ i OC kod muškaraca sa HSI, i vrednosti OC i $\beta$-CTx su povećane kod pacijenata u rastućim $\mathrm{Cis} C$ tercijarima. $U$ multivarijantnoj regresionoj analizi je pokazano da su OC i pušenje

Address for correspondence:

Prof. Biljana Bozic Nedeljkovic, PhD

University of Belgrade, Faculty of Biology

Studentski trg 16, 11000 Belgrade, Serbia

Phone/Fax: +381113032356

e-mail: biljana@bio.bg.ac.rs, najbiljana@yahoo.com 
$\mathrm{OC}$ and smoking were a significant determinant of $\mathrm{Cys} C$ in males with CHF. Level of CysC was found to be positively associated with an increased fatal risk in males with CHF. Conclusions: Serum osteocalcin is an independent predictor of CysC level in elderly males with CHF. Higher CysC level showed a negative relation to survival and bone loss in males with CHF. Further research is needed to confirm the potential role of $\mathrm{Cys} C$ in the crosstalk between heart, kidney, bone, and energy metabolism in CHF.

Keywords: Cystatin C, osteocalcin, bone turnover markers, bone mineral density, chronic heart failure

\section{Introduction}

Chronic heart failure (CHF) and chronic kidney injury are two common chronic conditions in elderly adults that due to the association with morbidity/mortality are gaining increasing importance in healthcare system (1). Investigations directed to elucidating common pathological mechanisms are necessary.

It is well established that CHF is a complex interplay among genetic, neurohormonal, biochemical, and inflammatory changes (2). The interaction between heart and renal dysfunction has been an area of considerable interest of research in recent years. It is assumed that $\mathrm{CHF}$ is a condition characterized by the association of chronic inflammatory process in the heart and impairment of the renal function. In regard of that trend the term "cardiorenal syndrome " has been proposed to outline the interplay between simultaneous heart and renal dysfunctions, and to analyse the biochemical changes, which have influenced both heart and kidney functions (3).

Cystatin $\mathrm{C}(\mathrm{Cys} \mathrm{C})$ is a small protein molecule belonging to cysteine protease inhibitors family with its main biological role being extracellular inhibition of cathepsins. Cys $C$ is freely filtered by the renal glomerulus and then reabsorbed and fully catabolized by proximal renal tubules, afterwards excreted into the bloodstream without creating a complex with other secreted proteins in the blood. It is a good endogenous biomarker of kidney function/glomerular filtration ratio (4-6). Furthermore, it was found to be associated with heart extracellular matrix remodelling. The activated oxidants in the failing heart induce elevated $\mathrm{Cys} C$ production from cardiomyocytes (7). Increased $\mathrm{Cys} C$ level is related to a variety of cardiovascular pathological conditions that have influence on renal function (8-10). Higher levels of $\mathrm{Cys} C$ were associated with an increased overall/cardiovascular cause of mortality in the population based cohort of ambulatory elderly persons (11). The Cys C concentration is additionally an independent risk factor for heart failure in older adults (12). Therefore, serum Cys $\mathrm{C}$ may be a useful surrogate marker of cardiovascular pathology. However, there are many unclear značajne determinante nivoa CisC kod muškaraca sa HSI Nivo $\mathrm{Cis} C$ je u pozitivnoj korelaciji sa povećanim rizikom za mortalitet kod muškaraca sa HSI.

Zaključak: Serumski osteokalcin je nezavisan prediktor nivoa CisC kod starijih muškaraca sa HSI. Povećan nivo CisC je pokazao negativnu povezanost sa preživljanjem i gubitkom kosti kod muškaraca sa HSI. Potrebno je da buduća istraživanja potvrde potencijalnu ulogu $\mathrm{Cis} C$ u komunikaciji između srca, bubrega, kosti i energetskog metabolizma u hroničnoj srčanoj insuficijenciji.

Ključne reči: Cistatin C, osteokalcin, marker metabolizma kosti, mineralna koštana gustina, hronična srčana insuficijencija

facts about $\mathrm{Cys} C$ as a marker for heart failure and its prognostic value in CHF. It is not clear which factors influence serum $\mathrm{Cys}_{\mathrm{s}} \mathrm{C}$ values and there is not sufficient literature data about correlation of $\mathrm{Cys} C$ values with other pathological processes associated with $\mathrm{CHF}$, such as bone loss and metabolic syndrome.

Osteoporosis is the additional multifactorial pathological condition in elderly adults associated with poor quality of life and morbidity/mortality (13). Patients with heart failure have been reported to have lower bone mineral density, in part related to lower vitamin $D$ and have higher frailty rates (14). The majority of available data indicates that the disturbances in bone turnover and the degree of bone loss are only subtle in $\mathrm{CHF}$ patients (15). There are data that Cys C could be a promising biomarker for identification of elderly adults at high risk of hip fracture. Higher serum $\mathrm{Cys} C$ is associated with an increased risk of hip fracture in elderly postmenopausal white females (16), but there is a paucity of data for males (17).

Consistent to our research aims in previous papers, we would like to continue investigation of crosstalk in cardiovascular-bone axis in CHF. The aim of our prospective investigation was to investigate the associations of $\mathrm{Cys} C$ as the confirming biomarker of renal dysfunction, with biochemical markers of bone turnover and mass in a group of elderly males with $\mathrm{CHF}$. Additionally, we intended to analyze the determinants of increased $\mathrm{Cys} \mathrm{C}$ in $\mathrm{CHF}$ and to evaluate the prognostic power of Cys $\mathrm{C}$ for $\mathrm{CHF}$ and for six-year mortality in CHF patients.

\section{Materials and Methods}

\section{Study population}

The study population of this longitudinal prospective cohort study, which included 68 elderly male patients with $\mathrm{CHF}$, has previously been characterized in detail by inclusion and exclusion criteria $(18,19)$. The control group consisted of 19 healthy subjects (HS), who did not take any medications. No previous medical illness was reported. Written informed consent for recruitment into the study and for follow-up for ten 
years from recruitment was obtained from all subjects. The study was conducted according to the principles outlined in the Declaration of Helsinki and was approved by the Ethics Committee of the Clinical Medical Centre Zvezdara. All-cause mortality was evaluated after six years. The data on patients deaths was obtained by phone contact with their relatives.

\section{Clinical/cardiovascular assessment}

All CHF males were categorized according to the New York Heart Association (NYHA) criteria (20). A physical exam was performed to assess CHF stability. Six-minute walk test (21), two-dimensional Doppler echocardiographic examination (22), and grip strength determination (23) were measured according to standard protocols. Bone mineral density at lumbar spine (L1-L4) was estimated by using dual-energy-X-ray absorptiometry machine (Lunar prodigy advance, USA), according to standard protocol.

\section{Laboratory analysis}

Basal blood samples were taken at 8 a.m. from an antecubital vein within two consecutive months (March-April 2007). Serum samples were immediately deep frozen and kept at $-70{ }^{\circ} \mathrm{C}$ until assay. All molecules in blood samples were measured by the appropriate method given with detailed protocol in previous papers $(18,19)$.

Table I Baseline characteristics of elderly males with CHF and healthy subjects.

\begin{tabular}{|c|c|c|c|}
\hline & Males with CHF $(n=68)$ & Healthy subjects $(n=19)$ & $\mathrm{p}$ \\
\hline Age (years) & $68 \pm 7$ & $67 \pm 8$ & NS \\
\hline $\mathrm{BMI}\left(\mathrm{kg} / \mathrm{m}^{2}\right)$ & $27 \pm 5$ & $28 \pm 3$ & NS \\
\hline Waist $(\mathrm{cm})$ & $98 \pm 13$ & $100 \pm 7$ & NS \\
\hline Waist/hip ratio & $1.02 \pm 0.04$ & $1.01 \pm 0.06$ & NS \\
\hline \multicolumn{4}{|l|}{ NYHA functional class } \\
\hline NYHA class II, n (\%) & $51(75)$ & & \\
\hline NYHA class III, n (\%) & $17(25)$ & & \\
\hline \multicolumn{4}{|l|}{ Clinical histories } \\
\hline Duration of $\mathrm{CHF}$ (years) & $5 \pm 4$ & & \\
\hline Smoking former / active, n (\%) & $18(27)$ / 9 (13) & $3(16) / 5(26)$ & \\
\hline Ischemic / idiopathic dilatated CMP, n (\%) & $56(82) / 12(18)$ & & \\
\hline Mean blood pressure $(\mathrm{mmHg})$ & $101 \pm 12$ & $104 \pm 7$ & NS \\
\hline Hypertension, n (\%) & $43(63)$ & & \\
\hline Atrial fibrillation, $\mathrm{n}(\%)$ & $20(29)$ & & \\
\hline Pacemaker, n (\%) & $7(10)$ & & \\
\hline History of myocardial infarction, n (\%) & $43(63)$ & & \\
\hline \multicolumn{4}{|l|}{ Echocardiography } \\
\hline LVEDD $(\mathrm{mm})$ & $66 \pm 9$ & $49 \pm 4$ & $<0.0001 * * *$ \\
\hline LVEF (\%) & $29 \pm 8$ & $65 \pm 5$ & $<0.0001 * * *$ \\
\hline $\mathrm{E} /$ Em ratio & $21 \pm 11$ & $9 \pm 3$ & $<0.0001 * * *$ \\
\hline \multicolumn{4}{|l|}{ Physical performance } \\
\hline Six-minute walking distance $(\mathrm{m})$ & $406 \pm 84$ & $583 \pm 62$ & $<0.0001 * * *$ \\
\hline Grip strength $(\mathrm{kg})$ & $94 \pm 20$ & $115 \pm 18$ & $<0.0001 * * *$ \\
\hline \multicolumn{4}{|l|}{ Body composition } \\
\hline BMD L1-4 $\left(\mathrm{g} / \mathrm{cm}^{2}\right)$ & $1.094 \pm 0.179$ & $1.225 \pm 0.231$ & $0.010 *$ \\
\hline BMD L1-4 (T score) & $-1.03 \pm 1.49$ & $0.08 \pm 1.89$ & $0.008 * *$ \\
\hline BMD hip $\left(\mathrm{g} / \mathrm{cm}^{2}\right)$ & $0.880 \pm 0.157$ & $0.984 \pm 0.184$ & $0.015^{*}$ \\
\hline BMD hip (T score) & $-1.41 \pm 1.25$ & $-0.58 \pm 1.48$ & $0.017^{*}$ \\
\hline Fat mass & $21 \pm 9$ & $25 \pm 7$ & 0.052 \\
\hline Lean mass & $54 \pm 8$ & $57 \pm 4$ & $0.011 *$ \\
\hline
\end{tabular}

Data are expressed as mean $\pm \mathrm{SD}$ or absolute number (percentage)

$* * * \mathrm{p}<0.0001, * * \mathrm{p}<0.01,{ }^{*} \mathrm{p}<0.05$ elderly males with CHF vs. healthy subjects

$\mathrm{BMD}=$ bone mineral density, $\mathrm{BMI}=$ body mass index, $\mathrm{CMP}=$ cardiomyopathy, $\mathrm{E} / \mathrm{Em}=$ transmitral flow velocity of $\mathrm{E}$ wave/mitral annular velocity at septal side, LVEF=left ventricular ejection fraction, $L V E D D=$ left ventricular end-diastolic diameter, $N Y H A=N e w$ York Heart Association 


\section{Cystatin C determination}

The levels of $\mathrm{Cys} C$ in the stored deep frozen serum samples of patients and HS were measured by specific sandwich-type ELISA, developed at the Department of Biochemistry and Molecular Biology, Jo ef Stefan Institute and Krka, as described (24). A microtiter plate was coated with a rabbit-affinity purified anti-CysC polyclonal antibody. Recombinant human $\mathrm{Cys} C$ was used for preparation of calibration curves. Sera from patients were diluted 1: 100 prior to being applied to the walls of microtiter plate. As a detection antibody, 1A2 monoclonal antibody was used, conjugated to horseradish peroxidase. A substrate for peroxidase was 3,3', 5, ${ }^{\prime}$-tetramethylbenzidine liquid substrate system (TMB, Sigma). The reaction was stopped by addition of $2 \mathrm{~mol} / \mathrm{L} \mathrm{H}_{2} \mathrm{SO}_{4}$, and the absorbance was measured at $450 \mathrm{~nm}$ on minireader (TECAN, Sunrise). The measured values of diluted samples were compared with the calibration curve and expressed in $\mathrm{ng} / \mathrm{mL}$ of serum.

\section{Clinical/biohumoral characteristics}

The general baseline characteristics of $\mathrm{CHF}$ and HS are presented in Table I. The elderly males with
$\mathrm{CHF}$ had lower left ventricular ejection fraction, together with six-minute walking distance, grip strength, lean mass, and BMD, but greater LVEDD and $\mathrm{E} / \mathrm{Em}$ ratio.

As shown in Table II, males with CHF had significantly higher levels of NT-pro-BNP, PTH, OPG, RANKL, ALP, OC, $\beta-C T x$, and CysC, while $25(\mathrm{OH}) \mathrm{D}$ levels were lower compared to HS.

\section{Statistical analysis}

Descriptive statistics were presented as mean values with standard deviation or median with interquartile range for numeric variables, or as absolute numbers with percentages for categorical variables. Evaluation of normality was performed by Kolmogorov-Smirnov test. Student t-test was used to calculate differences between mean values. MannWhitney $U$-test was used to determine differences between median values. $\chi^{2}$-test tested differences in frequencies between the studied groups. Comparisons across three groups were done with ANOVA (group means). The Pearson coefficient was used for linear correlation between variables. Finally, since variables are inter-related, multivariate regression

Table II Baseline values of biochemical parameters in elderly males with CHF and healthy subjects.

\begin{tabular}{|c|c|c|c|c|}
\hline & Males with $\mathrm{CHF}(\mathrm{n}=68)$ & Healthy subjects $(n=19)$ & $\mathrm{p}$ value & \\
\hline Cleareance creatinine $(\mathrm{mL} / \mathrm{min})$ & $63 \pm 22$ & $80 \pm 13$ & $0.002 * *$ & \\
\hline Creatinine $(\mu \mathrm{mol} / \mathrm{L})$ & $119.6 \pm 28.6$ & $99.7 \pm 12.9$ & $0.004 * *$ & \\
\hline BUN (mmol/L) & $8.5 \pm 3.8$ & $6.3 \pm 1.6$ & $0.019 *$ & \\
\hline Uric acid $(\mu \mathrm{mol} / \mathrm{L})$ & $414 \pm 106$ & $371 \pm 192$ & NS & \\
\hline Urin $\mathrm{Ca}(\mathrm{mmol} / \mathrm{L})$ & $2.3 \pm 1.5$ & $3.7 \pm 2.4$ & $0.004 * *$ & \\
\hline $\mathrm{hsCRP}(\mathrm{mg} / \mathrm{L})$ & $5.40 \pm 9.74$ & $2.87 \pm 3.77$ & NS & \\
\hline Serum albumin $(\mathrm{g} / \mathrm{L})$ & $43 \pm 3$ & $45 \pm 3$ & NS & \\
\hline Glucose (mmol/L) & $5.3 \pm 0.6$ & $5.6 \pm 0.5$ & NS & \\
\hline Cholesterol (mmol/L) & $5.5 \pm 1.1$ & $5.9 \pm 0.9$ & NS & Mean \pm SD \\
\hline Trigliceridi (mmol/L) & $1.6 \pm 0.6$ & $1.7 \pm 1.2$ & NS & \\
\hline $\mathrm{HDL}(\mathrm{mmol} / \mathrm{L})$ & $1.28 \pm 0.34$ & $1.45 \pm 0.42$ & NS & \\
\hline $\mathrm{LDL}(\mathrm{mmol} / \mathrm{L})$ & $3.54 \pm 0.94$ & $3.76 \pm 0.80$ & NS & \\
\hline 25(OH)D (nmol/L) & $31.9 \pm 14.8$ & $48.9 \pm 22.0$ & $<0.0001 * * *$ & \\
\hline PTH $(\mathrm{pg} / \mathrm{mL})$ & $78.3 \pm 33.8$ & $39.9 \pm 11.7$ & $<0.0001 * * *$ & \\
\hline $\operatorname{ALP}(\mathrm{U} / \mathrm{L})$ & $81.5 \pm 28.4$ & $67.7 \pm 19.2$ & 0.018 * & \\
\hline $\mathrm{OC}(\mathrm{ng} / \mathrm{ml})$ & $38.3 \pm 19.1$ & $29.2 \pm 7.7$ & $0.047 *$ & \\
\hline$\beta-C T x(p g / m L)$ & $517 \pm 278$ & $375 \pm 159$ & $0.036 *$ & \\
\hline Cystatin C (pg/mL) & $1354 \pm 427$ & $1125 \pm 301$ & $0.031 *$ & \\
\hline NT-pro-BNP $(\mathrm{pg} / \mathrm{mL})$ & $1809(2742)$ & $67(74)$ & $<0.0001^{* * *}$ & \\
\hline OPG $(\mathrm{pg} / \mathrm{mL})$ & $79.8(121.7)$ & $10.8(63.5)$ & $<0.0001 * * *$ & $M e \pm I Q R$ \\
\hline RANKL $(\mathrm{pg} / \mathrm{mL})$ & $130.9(125.8)$ & $47.8(44.4)$ & $<0.0001 * * *$ & \\
\hline
\end{tabular}

Data are expressed as mean \pm standard deviation (Mean \pm SD) or median \pm interquartile range (Me \pm IQR)

${ }^{* * *} \mathrm{p}<0.0001,{ }^{* *} \mathrm{p}<0.01,{ }^{*} \mathrm{p}<0.05$, elderly males with CHF vs. healthy subjects

$A L P=$ alkaline phosphatase, $B U N=$ blood urea nitrogen, $25(\mathrm{OH}) \mathrm{D}=25$-hydroxy vitamin $\mathrm{D}, \mathrm{NT}$-pro-BNP=N-terminal pro-brain natriuretic peptide, $\mathrm{OPG}=$ osteoprotegerin, $\mathrm{OC}=$ osteocalcin, $\beta-C T x-\beta=C$ rossLaps, HDL $=$ High Density Lipoprotein, LDL $=\mathrm{L}$ Density Lipoprotein, $\mathrm{PTH}=$ parathyroid hormone, $\mathrm{sRANKL}=$ serum receptor activator of nuclear factor $\kappa \mathrm{B}$ ligand 
analysis, stepwise method, was performed to assess the independent variables that may explain $\mathrm{Cys} C$ variability. The probability of $F$ was used to select the variables to be included in the model, the variables with $\mathrm{p}$-values less than 0.05 were entered and variables with $\mathrm{p}$-values larger than 0.10 were removed from the model. A $p<0.05$ was considered to indicate statistical significance. Statistical analysis was performed using the SPSS software (Chicago, IL).

\section{Results}

\section{CysC level in elderly CHF males}

The elderly males with CHF had significantly higher serum CysC level than HS (Table II). Additionally, we demonstrated that elderly males with $\mathrm{CHF}$ NYHAIll had significantly higher CysC levels compared to HS $(1433 \pm 99$ vs. $1125 \pm 301 \mathrm{pg} / \mathrm{mL}, \mathrm{p}=$ 0.014).

Further, ROC analysis was performed to evaluate sensitivity and specificity of $\mathrm{Cys} C$ between the groups studied. The area under the ROC curve for CysC levels was $0.659(95 \% \mathrm{Cl} 0.537-0.785)$, $\mathrm{p}<0.034$ (Figure 1). It was a low but statistically significant for $\mathrm{CHF}$ discrimination in comparison to $\mathrm{HS}$. The calculated $\mathrm{P} / \mathrm{N}$ ratio for CysC levels was 1250 $\mathrm{pg} / \mathrm{mL}$ (sensitivity 0.42 ; specificity 0.58 ).

\section{Relations between CysC with clinical/ biohumoral characteristics}

Correlation analysis of $\mathrm{Cys} C$ with various clinical/biohumoral parameters in $\mathrm{CHF}$ and $\mathrm{HS}$ are shown in Table III.

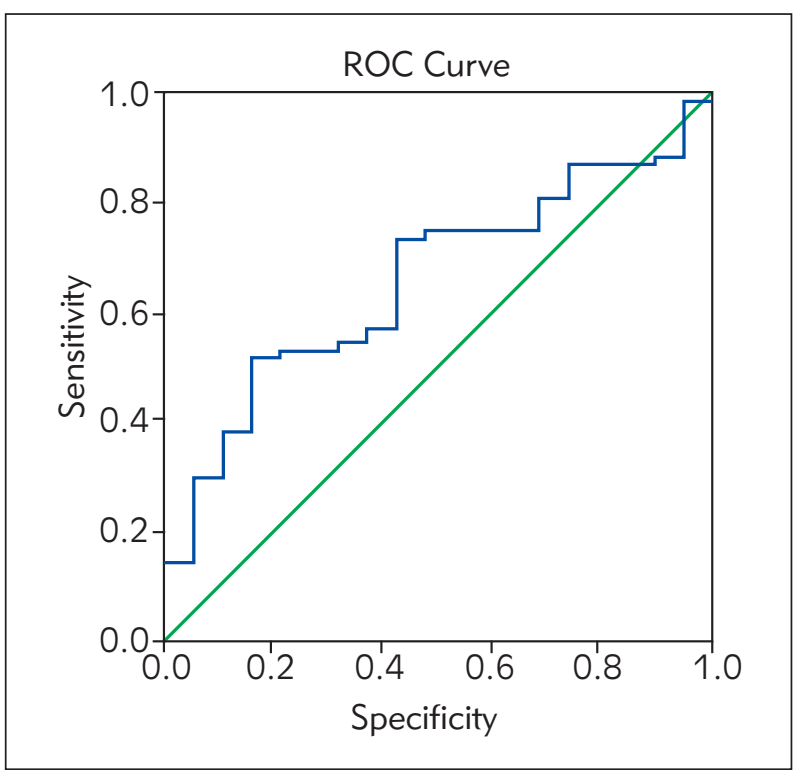

Figure 1 Receiver operator characteristic (ROC) curves for detection of chronic systolic heart failure in elderly males by CysC.
In HS CysC level was positively associated with age, BMD, and with tendency to statistical significance of cholesterol and OPG levels, while it was negatively associated with clearance of creatinine, sixminute walk test, lean mass and PTH (with tendency to statistical significance). All presented associations in HS were non-existent in CHF. On the other hand, in $\mathrm{CHF}$ Cys $\mathrm{C}$ level was positively associated with mean blood pressure and levels of cholesterol, LDL and OC, which was not evident in $\mathrm{HS}$.

Although, in CHF the association between CysC and age was not detected, the potential impact of age and heart failure on $\mathrm{Cys} C$ levels was further evaluated. Figure II presents CysC levels in CHF and HS, grouped according to age tertiles. This analysis demonstrated that serum CysC levels were significantly higher in $\mathrm{CHF}$ in T1 and T2 age tertiles compared to $\mathrm{HS}$ in the same age tertiles. However, there was no difference in $\mathrm{Cys} C$ levels between $\mathrm{CHF}$ and $\mathrm{HS}$ at the highest age tertiles (T3). In addition, HS in T3 had a significantly increased Cys $\mathrm{C}$ levels compared to $\mathrm{HS}$ in T1 age tertiles.

Table III Association of $\mathrm{Cys} C$ values with biochemical and clinical variables in elderly males with $\mathrm{CHF}$ and healthy subjects.

\begin{tabular}{|c|c|c|}
\hline & \multicolumn{2}{|c|}{ Cystatin C } \\
\hline & Healthy subjects & $\mathrm{CHF}$ \\
\hline $\begin{array}{l}\text { Age } \\
r(p)\end{array}$ & $0.666(0.002)$ & NS \\
\hline $\begin{array}{l}\text { Smoking } \\
r(p)\end{array}$ & NS & $0.335(0.005)$ \\
\hline $\begin{array}{l}\text { Clearance creatinine } \\
r(p)\end{array}$ & $-0.615(0.005)$ & NS \\
\hline $\begin{array}{l}\text { Cholesterol } \\
r(p)\end{array}$ & $0.446(0.056)$ & $0.269(0.027)$ \\
\hline $\begin{array}{l}\text { LDL } \\
r(p)\end{array}$ & NS & $0.240(0.048)$ \\
\hline $\begin{array}{l}\text { Mean blood pressure } \\
r(p)\end{array}$ & NS & $0.291(0.016)$ \\
\hline $\begin{array}{l}\text { Six-minute } \\
r(p)\end{array}$ & $-0.517(0.024)$ & NS \\
\hline $\begin{array}{l}\text { Lean mass } \\
r(p)\end{array}$ & $-0.530(0.020)$ & NS \\
\hline $\begin{array}{l}\text { BMD L1-L4 T g/ } \mathrm{cm}^{2} \\
r(p)\end{array}$ & $0.538(0.017)$ & NS \\
\hline $\begin{array}{l}\text { BMD L1-L4 T score } \\
r(p)\end{array}$ & $0.539(0.017)$ & NS \\
\hline $\begin{array}{l}\text { PTH } \\
r(p)\end{array}$ & $-0.452(0.052)$ & NS \\
\hline $\begin{array}{l}\text { OPG (log-transformed) } \\
r(p) \\
\text { OC }\end{array}$ & $0.454(0.051)$ & NS \\
\hline$r(p)$ & NS & $0.289(0.017)$ \\
\hline
\end{tabular}

$\mathrm{BMP}=$ Bone Mineral Density; LDL=Low Density Lipoprotein; $\mathrm{OPG}=$ Osteprotegerin; $\mathrm{OC}=$ Osteocalcin; $\mathrm{PTH}=$ Parathyroid Hormone 


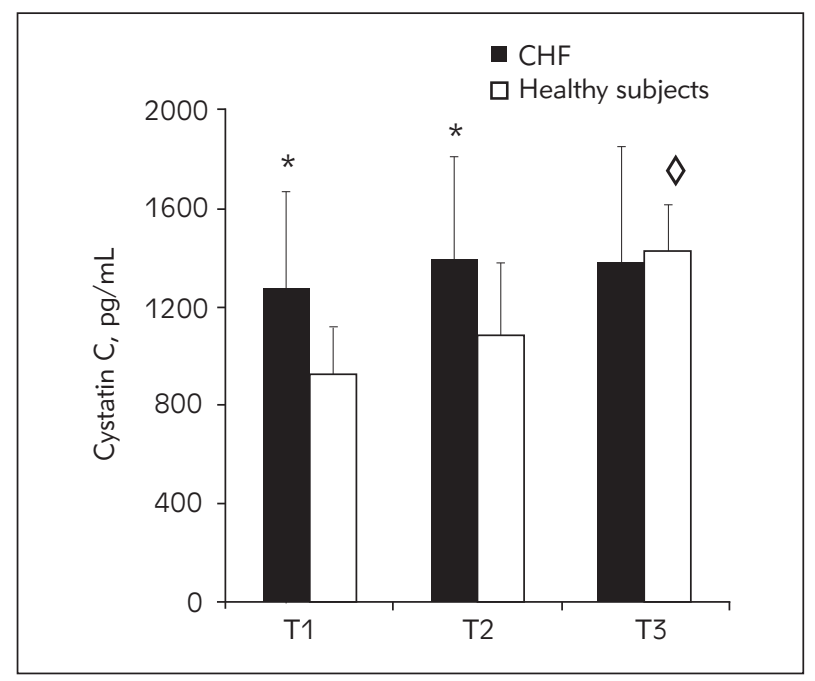

Figure 2 Serum CysC levels in elderly males with $\mathrm{CHF}$ and healthy subjects according to age tertiles.

( $\mathrm{T} 1=$ lowest to $\mathrm{T3}=$ highest)

Data are expressed as mean \pm standard deviation (Mean \pm $\mathrm{SD})$

${ }^{*} \mathrm{p}<0.05, \mathrm{CHF}$ vs. healthy subjects

$\diamond \mathrm{p}<0.05$, healthy subjects in T3 tertiles vs. T1 tertiles
Biochemical markers of bone turnover in elderly CHF males according to CysC tertiles

Levels of OC and $\beta$-CTx were significantly higher in the highest $\mathrm{Cys} C$ tertiles compared to middle CysC tertiles in $\mathrm{CHF}$, and for $\mathrm{OC}$ they appeared only in T1 (Figure III). ALP values in T3 were also significantly higher in comparison to T2 (87.2 28.9 vs. 68.4 \pm $20.2 \mathrm{U} / \mathrm{L}, \mathrm{p}=0.015)$.

Moreover, LVEF, LVEDD, and E/Em ratios were significantly impaired in the higher CysC tertiles. Levels of cholesterol and LDL were increased in the higher compared to lower CysC tertiles (Figure III).

\section{Multivariate logistic regression analysis}

A stepwise forward logistic regression analysis was performed. Odds ratio (OR), 95\% confidence intervals $(95 \% \mathrm{Cl})$ and Nagelkerke's $\mathrm{R}$ squared $\left(\mathrm{R}^{2}\right)$ are presented for the last stage (step 3) (Table IV). Independent association with $\mathrm{Cys} C$ levels, in $\mathrm{CHF}$, was noted for smoking and OC, which together had an $\mathrm{R}^{2}$ of 0.435 . Other included variables (age, CHF duration, $\mathrm{BNP}, \mathrm{ClCr}$, glucose, cholesterol, LDL, HDL, ALP,

\begin{tabular}{lcccccc}
\hline & T1 $(\mathrm{N}=22)$ & T2 $(\mathrm{N}=23)$ & T3 $(\mathrm{N}=23)$ & T1 vs T2 & T1 vs T3 & T2 vs T3 \\
\hline LVEF $(\%)$ & $31 \pm 7$ & $26 \pm 8$ & $29 \pm 8$ & 0.057 & & \\
LVEDD $(\mathrm{mm})$ & $63 \pm 8$ & $69 \pm 8$ & $66 \pm 10$ & 0.022 & & \\
E/Em ratio & $16 \pm 8$ & $22 \pm 11$ & $25 \pm 12$ & & 0.004 & \\
Cholesterol (mmol/L) & $5.3 \pm 1.0$ & $5.3 \pm 0.8$ & $6.0 \pm 1.2$ & & 0.033 & 0.015 \\
LDL cholesterol (mmol/L) & $3.28 \pm 0.93$ & $3.34 \pm 0.71$ & $3.98 \pm 1.03$ & & 0.021 & 0.018 \\
\hline
\end{tabular}
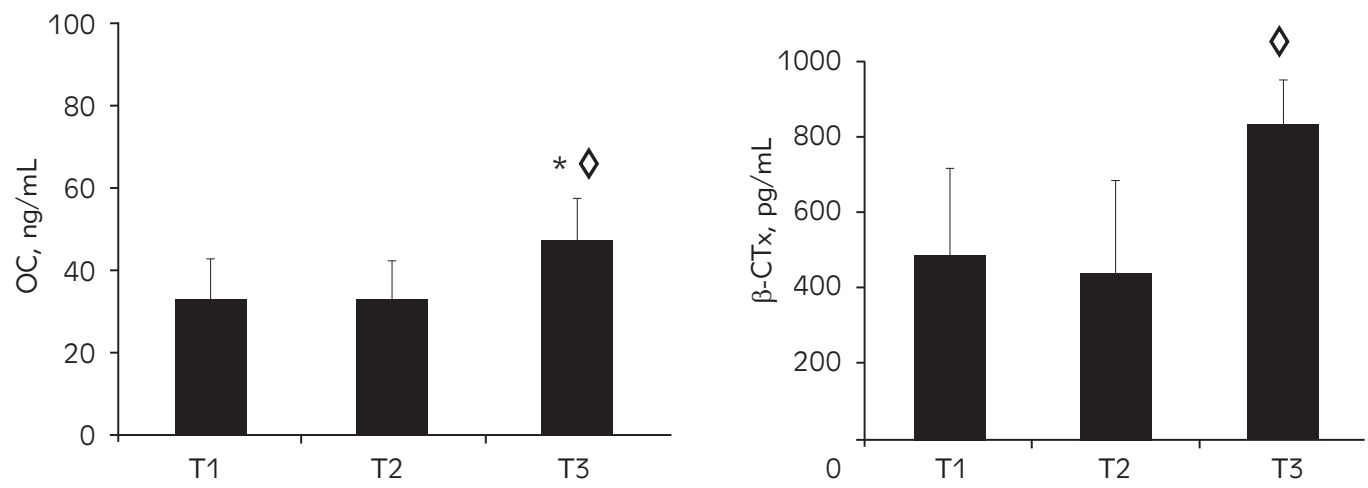

Figure 3 Some cardiovascular and metabolic parameters and serum osteocalcin and $\beta$ Cross-Laps levels in elderly males with $\mathrm{CHF}$ according to $\mathrm{Cys} C$ tertiles.

( $\mathrm{T} 1=$ lowest to $\mathrm{T3}=$ highest)

Data are expressed as mean \pm standard deviation (Mean \pm SD)

${ }^{*} \mathrm{p}<0.05, \mathrm{~T} 3$ vs. T1; $\diamond \mathrm{p}<0.05, \mathrm{T3}$ vs. T2

$\mathrm{LVEF}=$ Left Ventricular Ejection Fraction; $\mathrm{LVEDD}=$ Left Ventricular End-Diastolic Diameter; $E / E m=$ transmitral flow velocity of $E$ wave/ mitral annular motion velocity at septal side, $L D L=$ Low Density Lipoprotein, $O C=$ osteocalcin; $b-C T x=b$ Cross-Laps 
$\beta$-CTx, PTH, 25(OH) D, OPG, RANKL) showed a statistically insignificant contribution to the model. After finding that smoking influences the level of $\mathrm{Cys} C$ in $\mathrm{CHF}$ we compared the level of $\mathrm{Cys} C$ between smoking and non-smoking males with CHF. The smoking males with $\mathrm{CHF}$ had lower CysC level compared to non-smoking subjects with CHF (1104 \pm 485 vs. $1469 \pm 385 \mathrm{pg} / \mathrm{mL}, \mathrm{p}=0.018)$.

\section{Mortality of elderly CHF males according to CysC tertiles}

Survival curve for mortality according to CysC tertiles is presented in Figure IV. Levels of CysC were found to be positively associated with an increased risk of mortality in $\mathrm{CHF}$ (log-rank test, $\mathrm{p}>0.05)$. The elderly males with $\mathrm{CHF}$ in the highest CysC tertiles had a statistically significantly lower survival period

Table IV Multivariate regression analysis with $\mathrm{Cys} C$ as dependent variable.

\begin{tabular}{|l|c|c|c|}
\hline CHF patients & $\mathrm{B}$ & $\mathrm{p}$ & $\mathrm{F}$ \\
\hline Cystatin C & & & \\
(Constant) & 684.393 & & \\
Smoking & 186.446 & 0.007 & 7.458 \\
$\quad$ Osteocalcin & 5.717 & 0.027 & $(<0.0001)$ \\
$\quad \mathrm{R}^{2}=0.435$ & & & \\
\hline
\end{tabular}

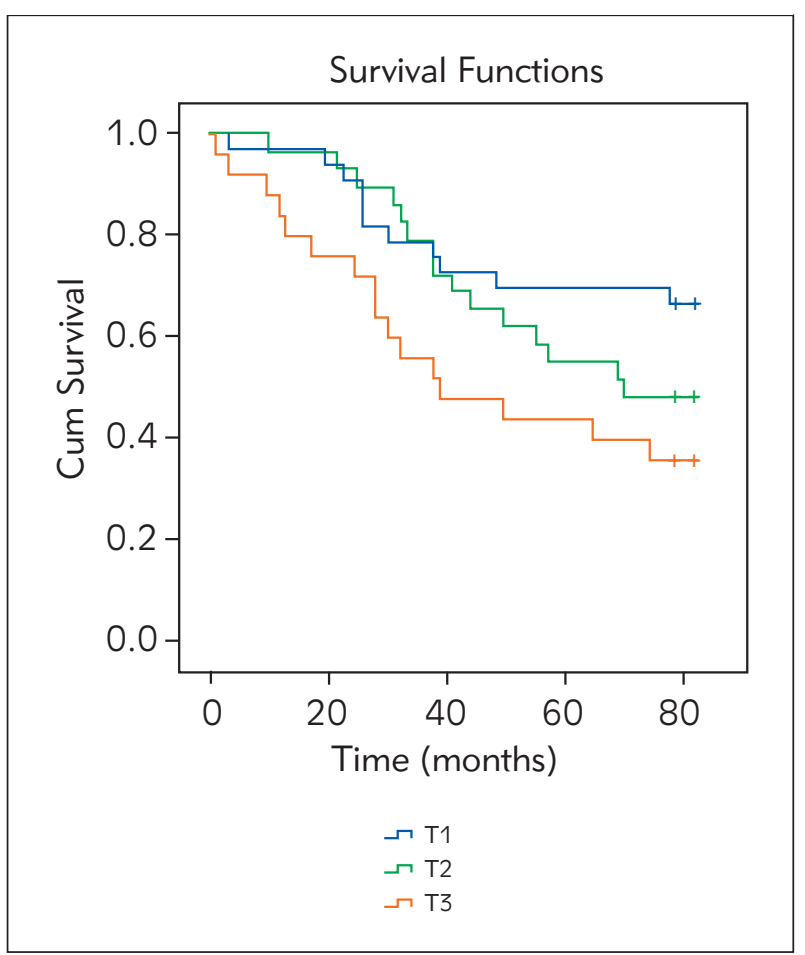

Figure 4 Survival curves of elderly males with $\mathrm{CHF}$ according to CysC tertiles compared to males with $\mathrm{CHF}$ in lower CysC tertiles. Additionally, we used Cox regression analysis for detection of mortality rate of elderly males with $\mathrm{CHF}$ grouped according to $\mathrm{Cys} C$ values adjusted for age and $\mathrm{ClCr}$ in the tertiles. Results of this analysis after adjustment confirmed that $\mathrm{CHF}$ in T3 had shorter survival period compared to T1 $(p=0.005)$.

\section{Discussion}

As far as we are aware, this is the first report of relation of bone turnover to levels of $\mathrm{Cys} C$ in elderly males with CHF. Our main findings are: 1) elderly males with $\mathrm{CHF}$ in the highest CysC tertiles have increased bone turnover (measured by level of bonederived substances); 2) increased $\mathrm{OC}$ is an independent determinant of $\mathrm{Cys} C$ in elderly males with $\mathrm{CHF}$; 3 ) elderly males with $\mathrm{CHF}$ and higher $\mathrm{Cys} C$ values had a decreased survival rate during the six-year-period, emphasising CysC as the prognostic marker of outcome in CHF. These findings are in line with the recent publication that bone-derived substances (25), some of which have hormonal properties, are related to CHF. Thus a new light was shed on the bone-cardiovascular axis. All these findings support the hypothesis that $\mathrm{Cys} C$ and $\mathrm{OC}$ may play a significant role in crosstalk between heart, bone, and kidney in CHF.

$\mathrm{Cys} C$ is a marker of renal function (5) and cardiovascular disease risk $(11,12)$, but its precise role in CHF has not been well established. CysC is associated with both more advanced left ventricular diastolic dysfunction and right ventricular systolic dysfunction; therefore it remains an independent predictor of long-term prognosis in chronic systolic (26). In line with previous studies we confirmed that Cys $\mathrm{C}$ levels were increased among elderly males with $\mathrm{CHF}$ in comparison to $\mathrm{HS}$. There was a significant relative risk of systolic CHF in elderly males associated with elevated CysC above the calculated cut-off of 1250 $\mathrm{pg} / \mathrm{mL}$. In agreement with previous studies presented in literature about the influence of CysC on CHF (11, 12), CHF patients in the T1 and T2 age tertiles had higher $\mathrm{Cys} \mathrm{C}$ values compared to $\mathrm{HS}$ in the same age tertiles. Additional confirmation of this finding was a significantly increased CysC level in elderly males with CHF NYHAIII compared to HS, while elderly males with CHF NYHAll had no statistically significantly increased $\mathrm{Cys} C$ values in the same comparison. On the contrary; there is no difference in $\mathrm{Cys} C$ values between $\mathrm{CHF}$ and HS in the highest age tertiles. The level of $\mathrm{Cys} C$ in the highest age tertiles in $\mathrm{HS}$ was significantly higher compared to the lowest age tertiles. Apparently, this result is in contrast to literature data. It was reported that $\mathrm{Cys} C$ production rate is not dependent on sex, age, body weight, or diet (27), but is altered by factors like inflammation, smoking status, corticosteroid treatment, and CRP level (28). Since the HSs in this study had normal renal function, did not use corticosteroids, and did not present ele- 
vated CRP levels, we may assume that smoking status and some other processes that have not been investigated, which are related to healthy ageing, had an influence on $\mathrm{Cys} C$ level in the oldest HS.

The level of $\mathrm{Cys} C$ is greatly influenced by thyroid function $(29,30)$. The thyroid hormones increase $\mathrm{Cys} C$ in vivo and stimulate $\mathrm{Cys} C$ production in bone cells in vitro (31). Firstly, an increased serum PTH was independently associated with various wellestablished parameters of heart failure progression, endothelial dysfunction, neuroendocrine activation (NT-pro-BNP, adiponectin) and could potentially be used to monitor progression of $\operatorname{CHF}(32,33)$. Although, PTH did not correlate with $\mathrm{Cys} C$ and there were no differences in PTH levels among males with $\mathrm{CHF}$ in different $\mathrm{Cys} C$ tertiles, we may assume that PTH alterations might be responsible for the increased levels of CysC in CHF. This hypothesis is supported by an increased bone turnover in the highest CysC tertiles. Secondly, body fat is a significant determinant of $\mathrm{Cys} C$. The highest $\mathrm{Cys} C$ level was detected in the group of obese healthy young males (34). The obesity should not influence the increased $\mathrm{Cys} \mathrm{C}$ in our CHF patients since all subjects were BMImatched and there were no differences in the total fat mass. Nevertheless, 31\% of CHF males were obese, while $20 \% \mathrm{HS}$ were obese. Visceral obesity was present in $59 \%$ of HF versus $50 \%$ in controls (19). Due to these facts the potential influence of fat on the increasing levels of Cys $\mathrm{C}$ in CHF cannot be excluded.

In the next part of study, we analyzed the association of $\mathrm{Cys} \mathrm{C}$ with other parameters. In $\mathrm{HS}$ we detected correlation between CysC and age. It is in agreement with higher $\mathrm{CysC}$ in older men ( $>59$ years) compared to middle-aged men ( $<59$ years) (35). On the other hand, the association of $\mathrm{Cys} C$ with age in our $\mathrm{HS}$ is contrary to literature data that CysC is not influenced by aging (27). The significant finding of this part of investigation is that all the associations of Cys C detected in HS were not detected in CHF. Contrary to that, new associations in CHF were detected. These findings support the hypothesis that production of Cys $\mathrm{C}$ is impaired and influenced by a lot of factors in $\mathrm{CHF}$, which may change its primary role in health. The negative associations of $\mathrm{Cys} C$ with physical performance expressed by six-minute walk and lean mass were noted in HSs in this study. This finding may be explained by the detected age-related $\mathrm{Cys} C$ elevation and age-related decrease in skeletal muscle mass, which is associated with functional limitation, disability, falls, and with a spectrum of various consequences $(36,37)$. However, our results are in contrast to the study of Baxmann and colleagues who did not detect any correlation between lean mass and $\mathrm{Cys} C$ in healthy males and females (38). These inconsistencies in CysC association with peripheral lean mass and physical performance may be attributed to differences in the studied groups. The patients in the study of Baxmann and colleagues were significantly younger, with different physical activities, and it was a mixed cohort of men and women. In elderly males with CHF these associations between $\mathrm{Cys} C$ and physical performance were not noticed. The reason for it might be a muscle alteration induced by $\mathrm{CHF}$, although our patients were noncachectic. This might bear responsibility for the reduction in functional performance in this cohort. It is in accordance with the claim that physical inactivity may be important in terms of peripheral muscle mass reduction (39). The positive correlation of $\mathrm{Cys} C$ and BMD in our HS might be explained by facts that CysC affects the BMP signalling cascades in osteoblastic cells and then promotes osteoblast differentiation, mineralization, and bone formation (40). This association was not detected in CHF males, thus indicating an impaired production of CysC in CHF. Additionally, our finding on positive correlation between Cys C and OPG in $\mathrm{HS}$ is in accordance with the previously published paper of Kulcsar-Jakab and colleagues (35). This correlation was not found in CHF males.

Currently, there is a growing interest in the potential roles of $\mathrm{Cys} C$ and $\mathrm{OC}$ in the metabolic syndrome, the regulation of glucose and fat metabolism. The association of cardiovascular disease and metabolic syndrome is well established (41). CysC level in CHF males positively associates with mean blood pressure and level of cholesterol and LDL as well. These associations do not show in HS. This is in line with results which suggest that $\mathrm{Cys} C$ may affect metabolic factors adversely thus contributing to the development of the metabolic syndrome (42). Results of this study may help to explain the link between CysC, metabolic changes (higher mean blood pressure, level of cholesterol and LDL) and the development of heart failure in elderly males. Further, we had shown that $\mathrm{Cys} C$ positively associates with $\mathrm{OC}$ in $\mathrm{CHF}$ males. This newly detected association between $\mathrm{Cys} C$ and $\mathrm{OC}$ in $\mathrm{CHF}$ was interesting for further analysis/investigation. This finding supports the involvement of both molecules, CysC and OC, in pathogenesis of heart failure in elderly population and related changes such as metabolic changes/syndrome and bone loss. Low OC levels are strongly associated with the metabolic syndrome in an elderly population (43). This is in agreement with our results that $\mathrm{CHF}$ males without metabolic syndrome presented the increased OC levels. Furthermore, it is in line with the finding of negative correlation between $\mathrm{OC}$ and fat mass in elderly males (44). Linking this with the result that CHF males with the highest $\mathrm{Cys} C$ had lower survival period compared to patients with lower $\mathrm{Cys} C$, and finding that $\mathrm{OC}$ is an independent determinant of $\mathrm{Cys} \mathrm{C}$ in $\mathrm{CHF}$, we may assume that $\mathrm{Cys} C$ and $\mathrm{OC}$ may have important roles, linking heart failure with bone metabolism, metabolic regulation, and energy homeostasis. Future studies are welcome in order to find a potential molecular link between these variables in $\mathrm{CHF}$. 


\section{Study limitations}

Several issues should be considered in the interpretation of our data. The principal limitation of our study is the relatively small sample size, which makes it impossible to draw firm conclusions in regard to hard endpoint. Secondly, our study was not originally designed to test the relation of CysC to CHF. Accordingly, it did not include information on other markers, which limits our insight into the mechanisms underlying the observed associations and interactions. Thirdly, the wide confidence intervals of the selected associations indicate a limited statistical strength. Thus, our study may lack precision in estimates of the observed associations and interactions, which suggests the need to replicate these findings in larger and other population samples in order to verify the strength of the observed associations. Finally, our results apply to a population of elderly CHF males without metabolic syndrome, diabetes, and cachexia. Thus, they are unlikely to apply to another CHF subpopulation.

In conclusion, the level of CysC was elevated in elderly CHF males and had adverse influence on the survival of these subjects. Increased CysC in CHF without the influence of metabolic syndrome, diabetes, and cachexia is independently determined by the increased OC. Our findings may indicate a crosssectional metabolic association of increased $\mathrm{Cys} C$ with increased level of bone turnover markers, espe-

\section{References}

1. Leibowitz D. Left ventricular hypertrophy and chronic renal insufficiency in the elderly. Cardiorenal Med 2014; 4: 168-75.

2. Braunwald E. Biomarkers in heart failure. $N$ Engl J Med 2008; 358: 2148-59.

3. Triposkiadis F, Starling RC, Boudoulas $\mathrm{H}$ et al. The cardiorenal syndrome in heart failure: cardiac? renal syndrome? Heart Fail Rev 2012; 17: 355-66.

4. Coll E, Botey A, Alvarez L et al. Serum cystatin C as a new marker for noninvasive estimation of glomerular filtration rate and as a marker for early renal impairment. Am J Kidney Dis 2000; 36: 29-34.

5. Fliser D, Ritz E. Serum cystatin C concentration as a marker of renal dysfunction in the elderly. Am J Kidney Dis 2001; 37: 79-83.

6. National Kidney Foundation Chronic Kidney Disease Guidelines. [(Accessed 4 January 2008)]. http: //www. kidney.org/professionals/KDOQI/guidelines_ckd/toc.htm

7. Xie L, Terrand J, Xu B et al. Cystatin C increases in cardiac injury: a role an extracellular matrix protein modulation. Cardiovasc Res 2010; 87: 628-35.

8. Moran A, Katz R, Smith NL et al. Cystatin C concentration as a predictor of systolic and diastolic heart failure. J Card Fail 2008; 14: 19-26. cially OC, and reduced bone mass in non-cachectic, non-diabetic, non-metabolic syndrome elderly $\mathrm{CHF}$ males. This bone-derived substance, OC, which influences $\mathrm{Cys} \mathrm{C}$ in $\mathrm{CHF}$, might place the bone at the centre of cardiovascular disease associated with chronic kidney disease. Most importantly, factors that indicate the inter-regulation of these substances in bone, heart, kidney, and other tissues such as fat and muscles, and subsequent secretion into the circulation, have not been investigated. They could provide entirely new avenues for therapeutic intervention. Future studies are welcome to evaluate the predictive values of $\mathrm{Cys} C$, to perform evaluation for clinical outcomes as well as for beneficial potential of $\mathrm{Cys} C$ or $\mathrm{OC}$ suppression in $\mathrm{CHF}$.

Acknowledgments. This work was supported by Serbian grant 175033, Slovenian grant P46811 and Bilateral Project between Slovenia and Serbia (principal investigators JK and BBN)

The abstract was presented at the $7^{\text {th }}$ Conference on Experimental and Translational Oncology (2013, Slovenia).

\section{Conflict of interest statement}

The authors state that they have no conflicts of interest regarding the publication of this article.
9. Ix JH, Shlipak MG, Chertow GM et al. Cystatin C, left ventricular hypertrophy, and diastolic dysfunction: data from the Heart and Soul Study. J Card Fail 2006; 12: 601-7.

10. Nosaka, Nakamura K, Kusano K et al. Cystatin C indicates diastolic dysfunction. Congest Heart Fail 2013; 19: E35-E39.

11. Shlipak MG, Sarnak MJ, Katz R et al. Cystatin $C$ and the risk of death and cardiovascular events among elderly persons. New Engl J Med 2005; 352: 2049-60.

12. Marković $D$, Jevtović-Stoimenov $R$, Ćosić $V$, Stošić $B$, Dinić V, Marković-Živković B, Janković JR. Clinical utility of survivin (BIRC5), novel cardiac biomarker, as a prognostic tool compared to high-sensitivity c-reactive protein, heart-type fatty acid binding protein and revised lee score in elderly patients scheduled for major non-cardiac surgery: a prospective pilot study. J Med Biochem 2018; 37: 110-20.

13. Prevention and management of osteoporosis. World Health Organ Tech Rep Ser. 2003; 921: 1-164. back cover

14. Tarighi S, Najafi M, Hossein-Nezhad A, Ghaedi $H$, Meshkani R, Moradi N, Fadaei R, Kazerouni F, Shanaki $M$. Association between two common polymorphisms of vitamin $D$ binding protein and the risk of coronary artery disease: A case-control study. J Med Biochem 2017; 36: 349-57. 
15. Zittermann A, Schleithoff SS, Koerfer R. Markers of bone metabolism in congestive heart failure. Clin Chim Acta 2006; 366: 27-36.

16. Fried LF, Biggs ML, Shlipak MG et al. Association of kidney function with incident hip fracture in older adults. J Am Soc Nephrol 2007; 18: 282-6.

17. Ensrud KE, Parimi N, Fink HA et al. Osteoporotic Fractures in Men Study Group. Estimated GFR and risk of hip fracture in older men: comparison of associations using cystatin C and creatinine. Am J Kidney Dis 2014; 63: 31-9.

18. Bozic B, Loncar G, Prodanovic N et al. Relationship Between High Circulating Adiponectin With Bone Mineral Density And Bone Metabolism In Elderly Males With Chronic Heart Failure. J Card Fail 2010; 16: 301-7.

19. Loncar G, Bozic B, von Haehling S et al. Association of adiponectin with peripheral muscle status in elderly patients with heart failure. Eur J Intern Med 2013; 24: 818-23.

20. The Criteria Committee of the New York Heart Association Criteria for diagnosis and treatment of heart failure. Little, Brown and Company, 1994.

21. ATS statement: guidelines for the six-minute walk test. ATS Committee on Proficiency Standards for Clinical Pulmonary Function Laboratories. Am J Respir Crit Care Med 2002; 166: 111-17.

22. Silvestry FE, Kerber RE, Brook MM et al. Echocardiography-guided interventions. J Am Soc Echocardiogr 2009; 22: 213-31.

23. Massy-Westropp N, Rankin W, Ahern M et al. Measuring grip strength in normal adults: Reference ranges and a comparison of electronic and hydraulic instruments. J Hand Surg Am 2004; 29: 514-9.

24. Kos J, Stabuc B, Schweiger A et al. Cathepsins B, H, and $L$ and their inhibitors stefin $A$ and cystatin $C$ in sera of melanoma patients. Clin Canc Res 1997; 3: 1815-22.

25. Vervloet MG, Massy ZA, Brandenburg VM et al; CKDMBD Working Group of ERA-EDTA Bone: a new endocrine organ at the heart of chronic kidney disease and mineral and bone disorders. Lancet Diabetes Endocrinol 2014; 2: 427-36.

26. Tang WH, Van Lente F, Shrestha K et al. Impact of myocardial function on cystatin $\mathrm{C}$ measurements in chronic systolic heart failure. J Card Fail 2008; 14: 394-9.

27. Newman DJ. Cystatin C. Ann Clin Biochem 2002; 39: 89-104.

28. Knight EL, Verhave JC, Spiegelman D, et al. Factors influencing serum cystatin $C$ levels other than renal function and the impact on renal function measurement. Kidney Int 2004; 65: 1416-21.

29. Fricker $M$, Wiesli $P$, Brandle $M$, et al. Impact of thyroid dysfunction on serum cystatin C. Kidney Int 2003; 63: 1944-7.

30. Wiesli P, Schwegler B, Spinas GA et al. Serum cystatin C is sensitive to small changes in thyroid function. Clin Chim Acta 2003; 338: 87-90.
31. Schmid C, Ghirlanda-Keller C, Zwimpfer C et al. Triiodothyronine stimulates cystatin $\mathrm{C}$ production in bone cells. Biochem Biophys Res Commun 2012; 419: 425-30.

32. Bozic B, Loncar G, Prodanovic N et al. Parathyroid hormone response to vitamin $D$ insufficiency in elderly males with chronic heart failure. Physiol Res 2011; 60: S155-63.

33. Loncar G, Bozic B, Dimkovic S et al. Association of increased parathyroid hormone with neuroendocrine activation and endothelial dysfunction in elderly men with heart failure. J Endocrinol Invest 2011; 34: e78-85.

34. Chew-Harris JS, Florkowski CM, George PM et al. The relative effects of fat versus muscle mass on cystatin $C$ and estimates of renal function in healthy young men. Ann Clin Biochem 2013; 50: 39-46.

35. Kulcsar-Jakab E, Petho Z, Pap Z et al. Cystatin C as a potential predictor of osteoprotegerin levels in healthy men, a cross-sectional, observational study. BMC Musculoskelet Disord 2015; 16: 227 . doi: 10.1186/ s12891-015-0684-1.

36. Baumgartner RN, Waters DL. Sarcopenia and sarcopenic obesity. In: Pathy MSJ, Sinclair AJ, Morley JE, editors. Principles and practice of geriatric medicine. West Sussex, England: JohnWiley \& Sons Ltd.; 2006. p. 909-34.

37. von Haehling S, Morley JE, Anker SD. An overview of sarcopenia: facts and numbers on prevalence and clinical impact. J Cachexia Sarcopenia Muscle 2010; 2: 129-33.

38. Baxmann AC, Ahmed MS, Marques NC et al. Influence of muscle mass and physical activity on serum and urinary creatinine and serum cystatin C. Clin J Am Soc Nephrol 2008; 3: 348-54.

39. Mancini DM, Walter $\mathrm{G}$, Reichek $\mathrm{N}$ et al. Contribution of skeletal muscle atrophy to exercise intolerance and altered muscle metabolism in heart failure. Circulation 1992; 85: 1364-73.

40. Danjo A, Yamaza T, Kido MA et al. Cystatin C stimulates the differentiation of mouse osteoblastic cells and bone formation. Biochem Biophys Res Commun 2007; 360: 199-204.

41. Emerging Risk Factors Collaboration, Wormser D, Kaptoge $S$ et al. Separate and combined associations of body-mass index and abdominal adiposity with cardiovascular disease: collaborative analysis of 58 prospective studies. Lancet 2011; 377: 1085-95.

42. Magnusson M, Hedblad B, Engström $G$ et al. High levels of cystatin $C$ predict the metabolic syndrome: the prospective Malmö Diet and Cancer Study. J Intern Med 2013; 274: 192-9.

43. Oosterwerff MM, van Schoor NM, Lips P et al. Osteocalcin as a predictor of the metabolic syndrome in older persons: a population-based study. Clin Endocrinol (Oxf) 2013; 78: 242-7.

44. Kindblom JM, Ohlsson C, Ljunggren $O$ et al. Plasma osteocalcin is inversely related to fat mass and plasma glucose in elderly Swedish men. J Bone Miner Res 2009; 24: 785-91. 